\title{
Cytomegalovirus pneumonitis and bone marrow transplantation: Identification of a specific high risk group
}

\author{
A B M Foot, E O Caul, A P Roome, J M Darville, A Oakhill
}

\begin{abstract}
Aims-To study the association between cytomegalovirus (CMV) excretion and interstitial pneumonitis in allogeneic bone marrow transplant (BMT) recipients, with reference to donor and recipient CMV antibody response.

Methods-The incidence of CMV excretion was prospectively studied in 62 allogeneic bone marrow transplantations performed on adults and children. All recipients received CMV seronegative blood products. Prophylaxis with high dose acyclovir and CMV immune globulin was given to high risk patients (donor or recipient, or both, CMV seropositive). Results-CMV excretion was detected in eight of $26(31 \%)$ high risk patients but in only one of 36 low risk patients (donor and recipient both CMV seronegative). Five of the eight (63\%) excretors in the high risk category developed CMV, of whom four $(80 \%)$ belonged to the seropositive recipient/seronegative donor group, and included the three CMV seropositive recipients whose CMV complement fixation antibody titres were 64 or greater before transplantation.

Conclusions-These findings suggest that there is a subgroup of patients at especially high risk of developing $\mathrm{CMV}$.
\end{abstract}

(F Clin Pathol 1993;46:415-419)

Disease caused by cytomegalovirus (CMV) continues to be the most important infectious complication following bone marrow transplantation (BMT).$^{1}$ In allogeneic transplantations it is most likely to occur in the first three months, and is second only to graft versus host disease (GvHD) as a cause of death, which in CMV infection results from the major complication of interstitial pneumonitis. Although there have been recent advances in the treatment of established CMV pneumonitis, combinations of antiviral agents and immune globulin (both high titre anti-CMV and normal) give variable results. Success is largely subject to ventilator dependency, and this treatment still fails to prevent death in most patients. ${ }^{2-4}$ Effective prophylaxis of primary infection, reinfection, or reactivation, would therefore be a major advance. The single most important risk factor for the occurrence of CMV pneumonitis following BMT is that of prior infection, although primary infection may also occur through infect- ed blood products, including the graft. Recent studies using CMV seronegative blood products, immune globulin, and antiviral agents, either singly or in combination, show variable success at prevention of disease. ${ }^{4-12}$

\section{Methods}

From October 1987 until June 1991, 61 patients received an allogeneic BMT on 62 occasions at the Royal Hospital for Sick Children, Bristol. The patients included 47 children less than 17 years of age at the time of transplantation (30 males, 17 females; median age $7 \cdot 7$ years), and 14 adults (10 men, four women; median age $29 \cdot 1$ years). One patient received a transplantation on two occasions from two separate donors. Grafts were from both related $(n=43)$ and unrelated donors $(n=19)$. In most cases the underlying disease requiring transplantation was leukaemia $(n=52)$. Other conditions treated were aplastic anaemia $(n=5)$, lymphoma ( $=2$ ), and single cases of Fanconi's anaemia and osteopetrosis. Marrow ablative conditioning regimens before BMT incorporated either combination chemotherapy and radiotherapy (given in fractionated form) or chemotherapy alone. Thirty seven patients also received $T$ cell depleted grafts using Campath 1M monoclonal antibody and $\mathrm{AB}$ serum as a source of complement, as described previously. ${ }^{13}$ Twenty three patients also received in vivo $T$ cell depletion using Campath 1G monoclonal antibody. GvHD prophylaxis with cyclosporin A was given to 27 patients, with additional methotrexate given to 14 patients.

CMV serology (complement fixation and latex agglutination) was performed on all donors and recipients included in the transplantation programme. Wherever possible, CMV seronegative donors were chosen. On $36(58 \%)$ occasions, both recipient and donor were CMV seronegative, and therefore at low risk of CMV infection. The remainder contributed to the high risk group, consisting of CMV seropositive recipient $(n=10), C M V$ seropositive donor $(n=8)$, and CMV seropositive recipient and donor $(n=8)$.

\section{PROPHYLAXIS}

All patients entered into the BMT programme received $\mathrm{CMV}$ seronegative blood products from the outset of treatment, in an attempt to prevent primary infection or reinfection by this route. This management was 
implemented regardless of CMV status, and continued throughout the period of blood product support. Screening of blood products was performed by the South West Regional Blood Transfusion Service using the CMV latex agglutination test.

In those cases where the recipient was considered to be at high risk of CMV infection, the following additional prophylactic measures were taken. High dose acyclovir (500 $\mathrm{mg} / \mathrm{m}^{2}$ intravenously three times daily) was given from day -7 to day +30 , and thereafter $200 \mathrm{mg}$ orally five times daily until day +100 . Either CMV hyperimmune globulin $\left(5 \mathrm{gm} / \mathrm{m}^{2}\right.$; Scottish National Blood Transfusion Service, CMV neutralising antibody titres of $>1 / 2000$ ) or immune globulin (200 $\mathrm{mg} / \mathrm{kg}$; Gamimmune, CMV complement fixation test titre of $>1 / 64$ ) was given intravenously on day -1 , day +13 , and then every three weeks to day +100 . All remaining recipients received low dose acyclovir alone $(5 \mathrm{mg} / \mathrm{kg}$ intravenously three times daily from day -7 ), converting to $200 \mathrm{mg}$ five times daily by mouth when oral nutrition had been re-established, until day +100 .

All recipients were scheduled to have CMV surveillance (nose and throat swabs, urine and serology) performed immediately before BMT, weekly while inpatients, and thence at outpatient check-ups to three months. Virological investigations were also carried out at any time when infection was suspected. When clinically indicated, induced sputum (IS) and bronchoalveolar lavage (BAL) specimens were also tested.

Patients' CMV antibody status was established by the latex agglutination test (CMV scan, Becton-Dickinson) and by the complement fixation test. Titres of CMV antibody were measured only by complement fixation test. Active infection was determined by virus isolation in cell culture both conventionally and by detection of early antigen fluorescent foci (DEAFF) using monoclonal antibodies both to early (Ortho) and early/late antigens (Syva).

Virological investigations were performed for a minimum of 100 days in all surviving cases. In the event of death with clinical suspicion of CMV, histological examination and virus culture were performed after necropsy whenever possible.

Statistical analyses were performed using the $\chi^{2}$, Fisher's exact, and the Kruskal-Wallis tests.

\section{Results}

The minimum follow up period of 100 days was achieved in 48 of the 61 (79\%) patients. The remainder died before this time, and death was associated with CMV infection in four of these patients.

Of the 36 patients in the low risk group, CMV infection occurred in one case despite the prophylactic measures described. This patient excreted CMV in urine from day 38 after BMT and day 11 after autologous rescue for acute rejection of the graft. The donor was seronegative one month prior to donation, but in the interim had developed a pyrexial illness with myalgia and fatigue. Unfortunately, further serological investigation of the donor was not possible. The patient was given therapeutic immune globulin $(200 \mathrm{mg} / \mathrm{kg}$ intravenously twice weekly), but no specific antiviral treatment, and did not develop any further signs of CMV disease.

Details of the 26 high risk transplantations (defined as seropositive recipient, donor, or both) are shown in tables 1,2 and 3. All patients apart from case 16 and case 24 received radiotherapy (fractionated) as part of their pre-BMT conditioning regimen. A median number of eight specimens was obtained from each of these patients for surveillance of CMV excretion, which was detected in eight (31\%), with interstitial pneumonitis developing in five (19\%) (tables 1-3). Although CMV excretors could be identified in all three of these subgroups (group A 5/10; group B 2/8; group C 1/8), it should be noted that all but one of those progressing to pneumonitis belonged to group A. Nineteen of these 26 high risk patients received $T$ cell depleted grafts, and included

Table 1 High risk cases and incidence of CMV infection: Group A (CMV seropositive* recipient with CMV seronegative donor)

\begin{tabular}{|c|c|c|c|c|c|c|c|}
\hline $\begin{array}{l}\text { Case No } \\
\text { (sex) }\end{array}$ & $\begin{array}{l}\text { Age } \\
(y)\end{array}$ & $\begin{array}{l}T \text { cellt } \\
\text { depletion }\end{array}$ & $G v H D$ & $\begin{array}{l}\text { CMV complement } \\
\text { fixation } \\
\text { test recipient }\end{array}$ & $\begin{array}{l}\text { CMV } \\
\text { excretor }\end{array}$ & $\begin{array}{l}\text { Interstitial } \\
\text { pneumonia }\end{array}$ & Outcome \\
\hline $1(M)$ & $17 \cdot 2$ & Yes $\star$ & No & 96 & \multirow{2}{*}{$\begin{array}{l}\text { Yes (D52) } \\
\text { BAL/urine } \\
\text { No }\end{array}$} & Yes & \multirow{7}{*}{$\begin{array}{l}\text { Died D65 } \\
\text { CMV interstitial pneumonia } \\
\text { Died D78 } \\
\text { Myocarditis } \\
\text { Died } 15 \mathrm{~m} \\
\text { Relapse } \\
\text { Died } 5 \mathrm{~m} \\
\text { Relapse } \\
\text { Well at } 2 \mathrm{y} \\
\text { Well at } 20 \mathrm{~m} \\
\text { Died D42 } \\
\text { CMV interstitial pneumonia } \\
\text { Proceeded to second BMT } \\
\text { Died D60 } \\
\text { CMV interstitial pneumonia } \\
\text { Died D168 } \\
\text { Systemic fungal infection }\end{array}$} \\
\hline $2(\mathrm{M})$ & $3 \cdot 8$ & Yes & No & 12 & & No & \\
\hline $3(\mathrm{M})$ & $8 \cdot 7$ & Yes & No & $<8$ & No & No & \\
\hline $4(\mathrm{M})$ & $8 \cdot 4$ & Yes & I & 12 & $\begin{array}{l}\text { Yes (D61) } \\
\text { IS }\end{array}$ & No & \\
\hline $\begin{array}{l}5(M) \\
6(M) \\
7(M)\end{array}$ & $\begin{array}{r}6 \cdot 3 \\
17 \cdot 3 \\
8 \cdot 1\end{array}$ & $\begin{array}{l}\text { Yes } \ddagger \\
\text { Yes } \\
\text { Yes }\end{array}$ & $\begin{array}{l}\text { I } \\
\text { No }\end{array}$ & $\begin{array}{r}48 \\
12 \\
192\end{array}$ & $\begin{array}{l}\text { No } \\
\text { No } \\
\text { Yes (D28) } \\
\text { BAL }\end{array}$ & $\begin{array}{l}\text { No } \\
\text { No } \\
\text { Yes }\end{array}$ & \\
\hline $\begin{array}{l}8(M) \\
9(M)\end{array}$ & $\begin{array}{r}17 \cdot 1 \\
8 \cdot 1\end{array}$ & $\begin{array}{l}\text { Yesł } \\
\text { Yes }\end{array}$ & $\begin{array}{l}\text { No } \\
\text { IV }\end{array}$ & $\begin{array}{l}24 \\
24\end{array}$ & $\begin{array}{l}\text { No } \\
\text { Yes (D25) } \\
\text { BAL }\end{array}$ & $\begin{array}{l}\text { No } \\
\text { Yes }\end{array}$ & \\
\hline $10(M)$ & $35 \cdot 2$ & No & IIH & 96 & $\begin{array}{l}\text { Yes (D49) } \\
\text { BAL }\end{array}$ & Yes & \\
\hline
\end{tabular}


Table 2 High risk cases and incidence of CMV infection: group B (CMV seropositive* recipient with $C M V$ seropositive* donor)

\begin{tabular}{|c|c|c|c|c|c|c|c|c|}
\hline \multirow{2}{*}{$\begin{array}{l}\text { Case No } \\
\text { (sex) }\end{array}$} & \multirow{2}{*}{$\begin{array}{l}\text { Age } \\
(y)\end{array}$} & \multirow{2}{*}{$\begin{array}{l}T \text { cellt } \\
\text { depletion }\end{array}$} & \multirow[b]{2}{*}{$G v H D$} & \multicolumn{2}{|c|}{$C M V$ complement fixation test } & \multirow{2}{*}{$\begin{array}{l}C M V \\
\text { exretor }\end{array}$} & \multirow{2}{*}{$\begin{array}{l}\text { Interstitial } \\
\text { pneumonia }\end{array}$} & \multirow[b]{2}{*}{ Outcome } \\
\hline & & & & Recipient & Donor & & & \\
\hline $\begin{array}{l}11(\mathrm{~F}) \\
12(\mathrm{M}) \\
13(\mathrm{M})\end{array}$ & $\begin{array}{r}32 \cdot 1 \\
12 \cdot 1 \\
9 \cdot 8\end{array}$ & $\begin{array}{l}\text { No } \\
\text { Yes } \\
\text { Yes }\end{array}$ & $\begin{array}{l}1 \text { §ा } \\
\text { III, c } \\
\text { IV, c }\end{array}$ & $\begin{array}{r}24 \\
8 \\
<8\end{array}$ & $\begin{array}{r}8 \\
16 \\
12\end{array}$ & \multirow{3}{*}{$\begin{array}{l}\text { No } \\
\text { No } \\
\text { Yes(D121) } \\
\text { Throat } \\
\text { No } \\
\text { Yes(D14) } \\
\text { IS } \\
\text { No } \\
\text { No } \\
\text { No }\end{array}$} & $\begin{array}{l}\text { No } \\
\text { No } \\
\text { No }\end{array}$ & \multirow{3}{*}{$\begin{array}{l}\text { Well at } 4 \mathrm{y} \\
\text { Well at } 2 \mathrm{y} \\
\text { Died } 6 \mathrm{~m} \\
\text { Liver GvHD } \\
\text { Well at } 18 \mathrm{~m} \\
\text { Died D25 } \\
\text { Aspergillus? } \\
\text { Well at } 10 \mathrm{~m} \\
\text { Well at } 5 \mathrm{~m} \\
\text { Well at } 5 \mathrm{~m}\end{array}$} \\
\hline $\begin{array}{l}14(\mathrm{~F}) \\
15(\mathrm{M})\end{array}$ & $\begin{array}{r}8 \cdot 3 \\
17 \cdot 4\end{array}$ & $\begin{array}{l}\text { Yesł } \\
\text { Yestt } \\
\text { (2nd) }\end{array}$ & IIई & $\begin{array}{l}24 \\
<8\end{array}$ & $\begin{array}{l}24 \\
\mathrm{ND}\end{array}$ & & $\begin{array}{l}\text { No } \\
\text { No }\end{array}$ & \\
\hline $\begin{array}{l}16(\mathrm{M}) \\
17(\mathrm{M}) \\
18(\mathrm{M})\end{array}$ & $\begin{array}{r}30.0 \\
7.7 \\
45.9\end{array}$ & $\begin{array}{l}\text { No } \\
\text { Yes } \\
\text { No }\end{array}$ & $\begin{array}{l}\text { NoßT } \\
\text { I§ } \\
11 \S\end{array}$ & $\begin{array}{l}12 \\
48 \\
48\end{array}$ & $\begin{array}{l}<8 \\
<8 \\
12\end{array}$ & & $\begin{array}{l}\text { No } \\
\text { No } \\
\text { No }\end{array}$ & \\
\hline
\end{tabular}

*All recipients and donors seropositive by latex agglutination test

twith Campath-1M and $A B$ serum as a source of complement

fin vivo $T$ cell depletion with Campath-1G $10 \mathrm{mg} /$ day $\times 5$ days

+ in vivo $T$ cell depletion with anti-lymphocyte globulin

\$ GvHD prophylaxis with cyclosporin A

TGvHD prophylaxis with methotrexate

$\mathrm{C}=$ chronic.

seven of the CMV excretors.

On statistical analysis, there was no correlation between either CMV excretion or interstitial pneumonia with type of BMT, incidence of $\mathrm{GvHD}$, age or radiotherapy, although our numbers are small. The association between CMV seronegative status in the donor and the development of interstitial pneumonia closely approached significance $(p=0.06)$. However, when the recipients' immediate pre-BMT CMV complement fixation test result was examined in the two relevant subgroups (tables 1 and 2), the titre was greater than 64 in only three patients, all of whom developed CMV interstitial pneumonitis. The relation between CMV complement fixation test titre and interstitial pneumonia was significant $(p<0.05)$.

Two of the three patients who excreted CMV without progressing to interstitial pneumonia, and all five of the patients who progressed to interstitial pneumonia received treatment with ganciclovir (10 $\mathrm{mg} / \mathrm{kg} /$ day) and immune globulin $(200 \mathrm{mg} / \mathrm{kg}$ twice weekly). But this pneumonitis proved fatal in all four who required ventilatory support. The fifth patient (case 10), had CMV identified on routine bronchoalveolar lavage at day 49 , immediately before developing the prodromal symptoms and signs of CMV interstitial pneumonia. As a result, this patient received targeted treatment at an earlier stage of the infection. Although he recovered clinically from this initial episode, bone marrow engraftment was poor and he died on day 168 from systemic fungal infection. At post mortem examination he had residual histological evidence of CMV in his lungs.

All seronegative recipients of grafts from seropositive donors became CMV seropositive by latex agglutination after the administration of CMV immune globulin. Most remained seronegative by complement fixation and, where antibody was shown, this never exceeded a titre of 12 . The one patient who was retested 18 months after transplantation had reverted to $\mathrm{CMV}$ seronegative status by latex agglutination, indicating that CMV had not been transferred with the donor marrow.

\section{Discussion}

Interstitial pneumonitis caused by CMV has severely impeded the success of BMT which otherwise offers the chance of cure for many potentially fatal conditions. Recent improvements in the prevention of GvHD, itself a significant contributory factor to the development of interstitial pneumonia, ${ }^{14}$ have succeeded in reducing this complication to some degree. This has been achieved by both modifications in immunosuppressive regimens and the use of immunoglobulin therapy. ${ }^{7}$

Table 3 High risk cases and incidence of CMV infection: group C (CMV seronegative recipient with CMV seropositive * donor)

\begin{tabular}{|c|c|c|c|c|c|c|c|}
\hline $\begin{array}{l}\text { Case No } \\
(\text { sex })\end{array}$ & $\begin{array}{l}A g e \\
(y)\end{array}$ & $\begin{array}{l}T \text { cellt } \\
\text { depletion }\end{array}$ & $G v H D$ & $\begin{array}{l}\text { CMV complement fixation } \\
\text { test donor }\end{array}$ & $\begin{array}{l}\text { CMV } \\
\text { excretor }\end{array}$ & $\begin{array}{l}\text { Interstitial } \\
\text { pneumonia }\end{array}$ & Outcome \\
\hline $\begin{array}{l}19(\mathrm{M}) \\
20(\mathrm{~F})\end{array}$ & $\begin{array}{r}6 \cdot 3 \\
14 \cdot 3\end{array}$ & $\begin{array}{l}\text { Yesł } \\
\text { Yes } \neq\end{array}$ & $\underset{\mathrm{II}}{\mathrm{II}}$ & $\begin{array}{l}12 \\
96\end{array}$ & $\begin{array}{l}\text { No } \\
\text { No }\end{array}$ & $\begin{array}{l}\text { No } \\
\text { No }\end{array}$ & \multirow{7}{*}{$\begin{array}{l}\text { Well at } 30 \mathrm{~m} \\
\text { Died } 7 \mathrm{~m} \\
\text { Relapse } \\
\text { Died } 9 \mathrm{~m} \\
\text { GvDH } \\
\text { Died } 4 \mathrm{~m} \\
\text { Relapse } \\
\text { Died D94 } \\
\text { CMV interstitial pneumonia } \\
\text { Died D47 } \\
\text { Graft rejection } \\
\text { Died } 5 \mathrm{~m} \\
\text { Relapse } \\
\text { Well } 5 \mathrm{~m}\end{array}$} \\
\hline $21(M)$ & $11 \cdot 2$ & Yesł & II,c & ND & No & No & \\
\hline $22(F)$ & $4 \cdot 1$ & Yesł & I & 12 & No & No & \\
\hline $23(\mathrm{M})$ & $6 \cdot 3$ & Yesł & Itt & 32 & $\begin{array}{l}\text { Yes(D89) } \\
\text { BAL }\end{array}$ & Yes & \\
\hline $24(M)$ & $34 \cdot 1$ & No & IIt+\$ & 8 & No & No & \\
\hline $25(F)$ & $9 \cdot 3$ & No & Itt & 24 & No & No & \\
\hline $26(M)$ & $12 \cdot 4$ & Noł & $\mathrm{IItt}$ & 64 & No & No & \\
\hline
\end{tabular}

^All donors seropositive by latex agglutination test

twith Campath-1M and $A B$ serum as a source of complemen

$\neq$ in vivo $T$ cell depletion with Campath-1G $10 \mathrm{mg} /$ day $\times 5$ days

HGvHD prophylaxis with cyclosporin $A$

$\S$ GvHD prophylaxis with methotrexate 
Although there have been advances in both prophylatic measures and therapeutic options for CMV disease in the past decade, however, this infection still remains a major clinical problem. It is now generally accepted that an immunological disorder must also have a significant role in the pathogenesis of CMV interstitial pneumonia. ${ }^{15}$ As the complication does not occur in all recipients, this suggests the existence of patients, at particularly high risk.

In this study, we have confirmed the low incidence of CMV infection in those recipients who were CMV seronegative and who received grafts from seronegative donors and screened blood products. ${ }^{68}$ In this group one case of CMV infection occurred and the occurrence of a viral like infection in the donor (already screened as CMV seronegative) immediately before harvest raises the possibility of primary CMV infection.

Graft rejection has previously been considered as another manifestation of CMV associated disease in the transplant setting. ${ }^{16}$ The efficacy of administration of CMV seronegative blood products to the other group of seronegative recipients at risk of primary infection (group C) is not generally so well documented. We concur with a previous report, however, which observed a lower incidence of CMV infections when managed in this way. ${ }^{17}$ Furthermore, the value of using seronegative products is confirmed by the finding in one patient that CMV had not been transmitted with the graft.

Considering all the high risk patients, the incidence of CMV excretion (31\%) and interstitial pneumonia $(19 \%)$ is an improvement on former rates $(69 \%$ and $24 \%$, respectively), ${ }^{14}$ and is comparable with those of other studies using immune globulin in a prophylactic regimen. ${ }^{7}$ This has largely been attributed to the associated reduction in GvHD. In our study, the incidence of GvHD in the 26 high risk patients was minimal, with only three patients having severe acute GvHD (grade III and IV) or chronic GvHD, or both. Despite this low rate, however, the incidence of CMV interstitial pneumonia was relatively high, occurring in almost two thirds of the excretors. Furthermore, the observation that all but one belonged to group $A$ requires explanation.

All but two of these patients (previously identified) received radiotherapy in a systematic fractionated form, as part of the marrow ablative regimen, and this is therefore unlikely to be a determining factor. $T$ cell depletion of the graft, however, was performed in 19 of the $26(73 \%)$, and including all but one of group $\mathrm{A}$. The high incidence of CMV interstitial pneumonia in this latter group (four of $10,40 \%$ in total; three of nine, $33 \%$ of $\mathrm{T}$ cell depleted) substantiates previous findings that $T$ cell depletion in a CMV seropositive recipient grafted from a non-immune donor is associated with a high risk of developing CMV interstitial pneumonia. ${ }^{18}$ It should be noted that the one patient with CMV interstitial pneumonia which did not immediately prove fatal (case 10) received a $\mathrm{T}$ cell replete graft, although he was also treated at an early stage of his illness. Of the $T$ cell depleted patients in group A, only patient case 4 treated aggressively at an early stage of CMV reactivation did not exhibit progressive disease.

In contrast, we support the observation that CMV seropositive donors in this situation seem to protect CMV seropositive recipients from developing severe disease as a result of CMV reactivation. In our study two patients out of eight in this category excreted CMV but none developed interstitial pneumonia.

We have noted the relevance of the immediate pre-transplant CMV complement fixation titres in our CMV seropositive recipients. Only three of 18 had antibody titres greater than 64 and all three developed interstitial pneumonia. In a large series collected by Meyers et al, no association could be identified between either the recipients' pre-transplant or donors' CMV titres and the subsequent development of $\mathrm{CMV}$ infection. ${ }^{14}$ However, in that study neither $\mathrm{T}$ cell depletion nor immunoglobulin prophylaxis was performed. On the other hand, our findings agree with those of Schmidt et al, who describe a higher proportion of patients with low pre-BMT CMV complement fixation titres $(<64)$ in their subsequently identified low risk group. In these, CMV was not identified in bronchoalveolar lavage fluid collected át day 35. ${ }^{19}$ Unfortunately, further relevant serological data concerning those who proceeded to develop CMV infection are not recorded.

Recent studies show major advances in addressing the problem of CMV interstitial pneumonia in BMT. For example, Atkinson et al report success in the prevention of CMV pneumonitis using prophylactic ganciclovir, before and after BMT, in all cases where either recipient or donor, or both, were seropositive. ${ }^{13}$ Haematological toxicity of this drug is, however, not uncommon. It was indeed possibly a contributing factor to the death of one of our patients (case 10). The identification of specific high risk patients before BMT would therefore provide the opportunity to give targeted prophylactic treatment and thus prevent unnecessary administration of a potentially toxic drug. Where $T$ cell depletion is practised, we would suggest that the measurement of the preBMT CMV complement fixation test titre might contribute to the identification of such a group. Our ongoing studies will refute or substantiate this theory.

We thank Bob Thorne and Amanda Dennis for the statistical analyses.

1 Meyers JD, Flournoy N, Thomas ED. Nonbacterial pneution: a review of ten years' experience. Rev Infect Dis 1982;4:1119-32.

2 Emmanuel D, Cunningham I, Jules-Elysee $\mathrm{K}$, et al. Cytomegalovirus pneumonia after bone marrow transplantation successfully treated with the combination of ganciclovir and high-dose intravenous immune globulin. Ann Intern Med 1988;109:777-82. 
3 Reed EC, Bowden RA, Dandliker PS, Lilleby KE, Meyers JD. Treatment of cytomegalovirus pneumonia with ganciclovir and intravenous cytomegalovirus immunoglobulin in patients with bone marrow transplants. Ann Intern Med 1988;109:783-8.

4 Verdonck LF, de Gast GC, Dekker AW, de Weger RA, Schuurman H-J, Rozenberg-Arska M. Treatment of

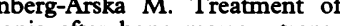
cytomegalovirus pneumonia after bone marrow transplanation with cytomegalovirus immunoglobulin combined with

5 Condie RM, O'Reilly RJ. Prevention of cytomegalovirus infection by prophylaxis with an intravenous, hyperimmune, native, unmodified cytomegalovirus globulin. $\mathrm{Am}$ $f$ Med 1984;76(3A): 134-41.

6 Bowden RA, Sayers M, Flournoy N, et al. Cytomegalovirus immune globulin and seronegative blood products to prevent primary cytomegalovirus infection after marrow transplantation. $N$ Engl $f$ Med 1986;314: 1006-10.

7 Winston DJ, Ho WG, Lin C-H, et al. Intravenous immune globulin for prevention of cytomegalovirus infection and interstitial pneumonia after bone marrow infection and interstitial pneumonia after bone

8 Mackinnon S, Burnett AK, Crawford RJ, et al. Seronegative blood products prevent primary cytomegalovirus infection after bone marrow transplantation. $f$ Clin Pathol 1988;41:948-50.

9 Meyers JD, Reed EC, Shepp DH, et al. Acyclovir for prevention of cytomegalovirus infection and disease after allogeneic marrow transplantation. $N$ Engl $\mathcal{F}$ Med 1988; 318:70-75.

10 Einsele H, Vallbracht A, Friese M, et al. Significant reduction of cytomegalovirus (CMV) disease by prophylaxis with CMV hyperimmune globulin plus oral acyclovir. with CMV hyperimmune globulin plus

11 Bowden RA, Fisher LD, Rogers K, Cays M, Meyers JD.
Cytomegalovirus (CMV) specific intravenous immunoglobulin for the prevention of primary CMV infection and disease after marrow transplant. $\mathcal{F}$ Infect Dis 1991; 164:483-7.

12 Atkinson K, Downs K, Golenia M, et al. Prophylactic use of ganciclovir in allogeneic bone marrow transplantation: absence of clinical cytomegalovirus infection. $\mathrm{Br} \mathcal{F}$ Haematol 1991;79:57-62.

13 Apperley JF, Jones L, Hale G, et al. Bone marrow transplantation for patients with chronic myeloid leukaemia: plantation for patients with chronic myeloid leukaemia: of graft versus host disease but may increase the risk of of graft versus host disease but may increase the risk of
leukaemic relapse. Bone Marrow Transplant 1986;1:53-66.

14 Meyers JD, Flournoy N, Thomas ED. Risk factors for cytomegalovirus infection after human marrow transplantation. F Infect Dis 1986;153:478-88.

15 Grundy JE, Shanley JD, Griffiths PD. Is cytomegalovirus interstitial pneumonitis in transplant recipients an immunopathological condition? Lancet 1987;ii:996-9.

16 May AG, Betts RF, Freeman RB, Andrus CH. An analysis of cytomegalovirus infection and HLA antigen matching on the outcome of renal transplantation. Ann matching on the outco

17 Winston DJ, Ho WG, Champlin RE. Ganciclovir and intravenous immunoglobulin in bone marrow transintravenous immunoglobulin in bone marrow trans-
plants. In: Champlin RE, Gale RP, eds. New strategies in plants. In: Champlin RE, Gale RP, eds. New strategies in bone marrow

18 Grob JP, Grundy JE, Prentice HG, et al. Immune donors can protect marrow-transplant recipients from severe cytomegalovirus infections. Lancet 1987;i:774-7.

19 Schmidt GH, Horak DA, Niland JC, et al. A randomized, controlled trial of prophylactic ganciclovir for cytomegalovirus pulmonary infection in recipients of allogeneic bone marrow transplants. $N$ Engl $f$ Med 1991; 324:1005-11. 